\title{
Psychological Forensic of Political Party Court Judges: Analysis of the Political Party Court Judges' Independence Based on the Law No. 2 of 2011 on the Change of the Law No. 2 of 2008 on Political Parties
}

\author{
Sultan Alwan', Rachmad Safa'at ${ }^{2}$, Sihabudin $^{3}$, Aan Eko Widiarto ${ }^{4}$ \\ ${ }^{I}$ Student Doctoral of Law, Universitas Brawijaya, Indonesia, ${ }^{2}$ Professor of Law, Universitas Brawijaya, Indonesia, \\ ${ }^{3}$ Associate Professor, Universitas Brawijaya, Indonesia, ${ }^{4}$ Associate Professor, Universitas Brawijaya, Indonesia
}

\begin{abstract}
The Political Party Court has been given a mandate by the Law No. 2 of 2011 on Political Parties to resolve the party's disputes. The research results show that there is an unclarity in the constitutional law on the requirements of the Political Party Court Judges and the mechanism to appoint them, which gives room for the parties to create their own mechanisms. Practically, this has caused problems, as the party's administration contributed in determining and appointing the Political Party Court Judge, even though those administrators have the potential to be one of the parties in the dispute trial due to the party's policies. This condition causes psychological and psychic pressures to the Party Judges. Thus, they cannot be independent in making verdicts in a trial. This fragility makes the Political Party Court Judge powerless in making verdicts in the internal level of the political parties.
\end{abstract}

Keyword: Psychology, Party, Court, Judge, independence, Law.

\section{Introduction}

The presence of political parties is a must in democratic and modern politics. ${ }^{1}$ This is because a democratic state is built upon a system of parties. ${ }^{2}$ A democratic mechanism which is carried out through direct election has changed the democratic paradigm in Indonesia, where there are the great desire and determination to choose the president and the vice in the parliament with the basis of every citizen's civil and political rights, as guaranteed in the constitution. ${ }^{3}$ This change of paradigm cannot be separated from the roles of the parties.

Political parties on one hand have the position as one of the democratic buffers for the governmental stability. ${ }^{4}$ On the other hand, they also become a facility for the citizens to channel their political aspirations and interests, both by being directly involved as the committee or as sympathizers. ${ }^{5}$ In the momentum of the democratic event, there are four general elections in every five years, which are the general election to choose legislative judges and the president, the election of governors, the election of regents/mayor, which are inseparable from the roles of the political parties.

In consequence, there are structural disputes, dismissals as party managers, laying off of judges without clear reasons. The party's structural disputes have happened since the pre-independence era, postindependence in the Old Order $\mathrm{Era}^{5}$, in the New Order $\mathrm{Era}^{6}$, and even in the Reformation Era. Yet, the political parties have not produced a strong construction of democratic politics in terms of its organization and in terms of a democratic public spirit ${ }^{7}$, especially in resolving internal political party disputes.

Since the issuing of the Law No. 2 of 2011 on the Change of the Law No. 2 of 2008 on Political Parties, and also as stated in the Republic of Indonesia Fascicles of 2011 No. 8, the resolution of political party disputes is carried out at the Political Party Court or that of other names which have such authority. This Court is formed internally, with the foundation of the party's basic budget and budget of the party's affairs. 
There are many problems caused by the placement of the Political Party Court as an internal part of the party and also the filling of the Political Party Court by the party's committee. On one hand, the Political Party Court gives the power to make a verdict on cases. But, on the other hand, it is an internal part of the party, thus there may be a conflict of interest, where there is the desire to protect their colleagues. Apart from that, the appointment of the Political Party Court judges involves the party's administrators. Ironically, the political party's administrators will be one of the parties which will have disputes and will process cases in the Political Party Court. Thus, this will produce a relation of patron-client, which has the potential to create an unequal attitude in the process of the political party dispute resolution.

The Political Party Court judges may experience psychological pressure in giving a verdict on the cases which involve the party's administration and also the party's leaders. The position of the Political Party Court as a member of the party under the administration of the Chairperson creates an unhealthy psychological condition. The problem of this research is, "Can the Political Party Court judges be independent in giving a verdict on the party's disputes in unhealthy psychic and psychological conditions?"

\section{Research Method}

This is a socio-legal type of research. This type of research is based on the normative-legal knowledge (the constitutional regulations) which then adjusts and compares with the reality, as the law in action ${ }^{8}$. This means that apart from analyzing and observing the research objects from the positive law point of view, it also analyzes the legal phenomenon in the society or the social facts.

\section{Discussion}

Experts of psychology in the past defined their field of study as the "study of mental activities." With the development of the behaviorism paradigm at the start of this century, where the emphasis of study is only things which may be measured objectively, psychology is then defined as "a behavioral study." The definition of psychology from the Great Indonesian Language Dictionary as quoted by Atkinson ${ }^{9}$ is the study which is related to mental processes, both normal and abnormal ones, and their influence towards the behavior.

The psychological approach towards the judges have the aim to analyze the judges' behaviors as legal subjects in seeing the occurring legal phenomena. This approach towards the judges emphasize the humans' ability in law, including from the laws and the judges' verdicts. The psychology of law assumes that the characteristics, the participants, and the condition may influence how a judge issues a verdict. In those characteristics, it includes the capability of those people as judges, their perspectives, their values, their experiences and also all factors which influence their behaviors. For example, will a judge personnel give a "guilty" verdict to a thief due to hunger? Will a judge from the A tribe have more sympathy towards a perpetrator whose tribe is also $\mathrm{A} ?^{10}$

In the psychological perspective of the judges, the behaviors of the participants in the legal system are not only results from their internal quality, but also from the environment where they worked at. ${ }^{11}$ The Political Party Court judges have the same dilemma, where they are psychically and psychologically influenced by the environment. Political parties have the obligation to form a Political Party Court or that of other names to resolve disputes which happen internally in the parties. Such disputes are resolved at the Political Party Court, by the Political Party Court judges, with all of their problems.

Table 1: Internal Dispute Resolution Institutions in Political Parties

\begin{tabular}{|c|l|l|l|l|}
\hline No. & $\begin{array}{l}\text { Political } \\
\text { Party }\end{array}$ & $\begin{array}{l}\text { Name of the Dispute } \\
\text { Resolution Institution }\end{array}$ & $\begin{array}{l}\text { Number of } \\
\text { Assemblies }\end{array}$ & $\begin{array}{l}\text { Registration Letter as noted by the Ministry of Law and } \\
\text { Human Rights }\end{array}$ \\
\hline 1 & PDIP & Party Court & 7 People & Number: M.HH.06.AH.11.01, on September 27, 2019. \\
\hline 2 & Gerindra & $\begin{array}{l}\text { Honorary Assembly of } \\
\text { Gerindra Party Central Board }\end{array}$ & 28 People & Number: AHU.4.AH.11.0-10, onAugust 13, 2019. \\
\hline 3 & Golkar & Assembly of Golkar Party & 7 People & Number: AHU.4.AH.11.01-13, February 3, 2020. \\
\hline 4 & PKB & Arbitration Assembly & 5 People & Number: AHU.4.AH.11.01.11, on August 22, 2019. \\
\hline 5 & NasDem & NasDem Party Court & 3 People & Number: 078-SE/DPP-Nasdem/VIII/2016, on August 31, 2016. \\
\hline
\end{tabular}




\begin{tabular}{|c|l|l|l|l|}
\hline No. & $\begin{array}{l}\text { Political } \\
\text { Party }\end{array}$ & $\begin{array}{l}\text { Name of the Dispute } \\
\text { Resolution Institution }\end{array}$ & $\begin{array}{l}\text { Number of } \\
\text { Assemblies }\end{array}$ & $\begin{array}{l}\text { Registration Letter as noted by the Ministry of Law and } \\
\text { Human Rights }\end{array}$ \\
\hline 6 & PKS & Arbitration Assembly & 5 People & Number: B-36/K/DPP-PKS/1437, on March 2, 2016. \\
\hline 7 & Demokrat & $\begin{array}{l}\text { Honorary Assembly/Demokrat } \\
\text { Party Court }\end{array}$ & 5 People & Number: AHU.4.AH.11.02-22, on October 16, 2017. \\
\hline 8 & PAN & PAN Party Court & 4 People & Number: M.HH-10.AH.11.01, on December 20, 2019. \\
\hline 9 & PPP & DPP PPP Party Court & 9 People & Number: M.HH-10.AH.11.01 on November 5, 2018. \\
\hline
\end{tabular}

Data processed from the Indonesian Ministry of Law and Human Rights: Based on the table above, there are different names of the dispute resolution institutions formed by Indonesia's various parties. There are also different numbers of the Political Party Court judges, or that of different names. The 2011 Law on Political Parties obliges all parties to submit the structure of the Political Party Court, or that of other names, to the Ministry of Law and Human Rights.

The Political Party Court judges who were appointed through the internal mechanism of the parties must be reported by the party to the Ministry of Law and Human Rights. According to A. A. Teohari (Head of the Political Party Sub-Directory of the Republic of Indonesia's Ministry of Law and Human Rights) in a conversation (February $17^{\text {th }}, 2020$ ), in practice, there are two types of such reports: "First, the political party only reports it as according to the stipulations of Article 32, where the Chairperson and the General Secretary sign a letter which delivers the Political Party Court structure. The second variety is, sometimes the Party will insert the Political Party Court structure to be included in the management structure."

The Political Party Court judges' scope of authority, as stipulated in Article 32 clause (5)No. 2011 of the Political Party Law are as follows: resolving management disputes, laying off cadres without clear reasons, misuse of power, financial accountability, objections on the party's decrees. It even states that in management disputes, the Political Party Court judges' verdicts are final and binding.

Then, in the practical level, the political party cadres have the perception that it is difficult for the Political Party Court judges to carry out their roles and functions by applying the principles of impartiality, justice, and objectivity. Such pessimistic attitude was uncovered from the statement of a Party Judge, Y. B. Badeode, a member of the Demokrat Party Court in a conversation (February $\left.28^{\text {th }}, 2020\right)$ :

... so that the Political Party Courtmay exist, it must be acknowledged by the party, and must be independent. It cannot be controlled by the Central Board nor the Chairperson. Yet, there is the concern that if the Political Party Court is too strong, it will be regarded as a second power, even though the Political Party Court is an internal part, thus it should be independent.

Then,M. Wahid, a Legislative member of Ternate City, a cadre of PPP, in a conversation (December $23^{\text {rd }}$, 2019) stated that:

... there is the potential of a conflict of interest when the Political Party Court issues a verdict. The term is "jeruk makan jeruk", which means that the Political Party Court is filled by people of that party, and the objects put on trial at that court are verdicts of the Political Party leaders, which means that they are the verdicts of that party itself. Then, there is a room for cadres to seek justice at the Political Party managers through the Political Party Court. This is where the objectivity is tested.

The political party members' perceptions influence their choice in determining the institution to resolve political party disputes who are believed as able to bring justice. The Political Party Court judges' psychological condition which are suspected as not independent makes the problematic cadres or administrators choose to resolve their issues through mechanisms other than through the Political Party Court, which is through a lawsuit to the District Court. 
Table 2: Choice Comparison of Party Dispute Resolution through the Party Court and through the District Court from 2011 to 2018

\begin{tabular}{|c|l|c|c|c|c|}
\hline \multirow{2}{*}{ No. } & \multirow{2}{*}{ Political Party } & \multicolumn{2}{|c|}{ Dismissal of Party Judge } & \multicolumn{2}{c|}{ Management Disputes } \\
\cline { 3 - 6 } & & \multicolumn{2}{|c|}{ Lawsuit through } & \multicolumn{2}{c|}{ Lawsuit through } \\
\cline { 2 - 6 } & & Political Party Court & District Court & Political Party Court & District Court \\
\hline 1 & Golkar & 1 & 15 & 3 & - \\
\hline 2 & PPP & - & 14 & 6 & 1 \\
\hline 3 & PAN & 8 & 12 & - & - \\
\hline 4 & Demokrat & 29 & 1 & - & - \\
\hline 5 & Gerindra & 1 & 5 & $\mathbf{9}$ & $\mathbf{2}$ \\
\hline \multicolumn{2}{|c|}{ Total } & $\mathbf{3 9}$ & $\mathbf{4 7}$ & & - \\
\hline
\end{tabular}

Source: Data processed from the Republic of Indonesia Supreme Court

Based on the data of the five political parties which were participants of the general election above, the problems are dominated by the case of dismissal of the parties' members, where there were 86 cases. Then, there were 13 cases which were related to the management. The data above show that in resolving the parties' cases, the cadres do not choose to resolve them through the Political Party Court. But they choose to send a lawsuit directly to the District Court.Then, according to Sulistiyono and Isharyanto the most basic form of courtly independence is the independence in issuing a verdict, which has reference to the judges' capabilities to decide upon a case independently according to the law, without the influence of other parties or other institutions. ${ }^{12}$

The personal independence of the Political Party Court judges is influenced by the relations between the party who appoint and the party who is appointed (patron-client). In this case, Political Party Court judges were chosen and appointed by the party's management. Thus, there is a high chance for a tolerant attitude to return the favor. This will influence the personal independence. This creates an unhealthy psychological condition for the Political Party Court judges as they cannot be objective.

According to Sulistiyono and Isharyanto, the impartial behavior in a courtly process may only be established if the judge may release him/herself from the conflict of interest or the collegial spirit with the parties in the trial. If a judge sees the potential for a conflict of interest in handling a case, thus that judge must step down. ${ }^{12}$
That is why, one of the requirements which must be fulfilled by a judge in handling a case is that there cannot be a conflict of interest. If there is a potential for it, that judge has the obligation to step down. The resignation of a judge in a District Court in handling a case where there is a conflict of interest is facultative. If the judge does not step down, it will imply to the invalidity of the verdict. $^{12}$

Principally, the main job of a court is to accept, investigate, judge, and resolve all cases which are proposed. According to Mertokusumo, "It is not an easy job to explore, follow, and understand the legal values which live in the society." 13 Thus, the profession as a judge is a job which needs adequate expertise, time, and knowledge to explore, understand, and judge a case based on the values of justice. That is why the law on Judicial Power gives very tight requirements to the judges.

Even so, the tight requirement to be appointed as judges, the noble task and the great responsibility in upholding the law and justice are not applied in filling the profession of judges in the Political Party Court. This is because the procedures in filling the Political Party Court judges are fully up to the party's mechanism. Thus, there is the tendency for a dominant subjective consideration in appointing the Political Party Court judges. Those who are appointed are the people who can work together with the party's managers. At least, those who are chosen have the tendency to make verdicts which side the interests of the party's managers. 
This patron-client relation in filling the Political Party Court judge position is against the nemo judex in rexsua principle, which believes that there is no good judge for him/herself. As an ius constituendum there needs to be a law on filling the Political Party Court judge position in the constitutional level by limiting the double position for the Political Party Court judges and accommodating Political Party Court judges from elements outside of the party who are independent, and who are appointed through the highest forum in making the party's decisions.

\section{Conclusion}

The Political Party Court judges experience psychological and psychic pressures which make them unable to act or give a verdict on the case in a party independently. The Political Party Court judges may be pressured by the party's managers or administrators due to their status as a party member, which may be laid off anytime.

Such unhealthy psychological and psychic condition of the Political Party Court judges is very clear. Thus, the party members prefer resolve disputes in the District Court rather than bringing it to the Political Party Court. They realize the Political Party Court judges' tendency to not be independent, and that as members of the party, they must comply with the party's leadership. But on the other hand, they must resolve disputes or conflicts which involve the party's administrators or managers.

\section{Conflict of Interest: No}

\section{Source of Funding: Author}

\section{Ethical Clearance: Yes}

\section{References}

1. Amal I, editor. Teori-teori mutakhir partai politik. 2nd ed. Yogyakarta: Tiara Wacana; 2012. v p.
2. Laski HJ. A grammar of politic, eleventh impression. London: George Allen \& Unwin Ltd; $1951.312 \mathrm{p}$.

3. Naharuddin A, Seniwati. Election in Indonesia after the fall of Soeharto. International Journal of Management and Applied Science. Jan 2016;2(1). http://www.iraj.in/journal/journal_file/journal_ pdf/14-223-1484742615162-165.pdf.

4. Firdaus. Constitutional engineering desain stabilitas pemerintahan demokrasi dan sistem kepartaian. Bandung: Yrama Widya; 2015. 12 p.

5. Suwito DDP. Aspek hukum perselisihan internal partai politik. Jakarta: Adhi Sarana Nusantara; 2017. 2 p.

6. Samson AA. Islam in Indonesian politics. In: Thaba AA. Islam dan negara dalam politik orde baru. Jakarta: Gema Insani Pers; 1996. 146 p.

7. Rachman A. Hukum perselisihan partai politik. Jakarta: Gramedia Pustaka Utama; 2016. 2 p.

8. Fajar M, Ahmad Y. Dualisme penelitian hukum normatif dan empiris. Yogyakarta: Pustaka Pelajar; 2013. 46-7 p.

9. Atkinson $\mathrm{R}$, et al. Pengantar psikologi. 8th ed. Jakarta: Putra Literasi; 1983. 18 p.

10. Putra MSJR. Tinjauan psikologi hukum terhadap pengambilan putusan oleh hakim pada delik perkosaan [master's thesis]. Makassar: Universitas Hasanuddin; 2017. 16-17 p.

11. Rahayu YP. Di balik putusan hakim, kajian psikologi hukum dalam perkara pidana. 2005. 4 p.

12. Sulistiyono A, Isharyanto. Sistem peradilan di Indonesia dalam teori dan praktik. Depok: Prenadamedia Group; 2018. v, 39 p.

13. Martokusumo S. Bunga rampai ilmu hukum. Yogyakarta: Liberty; 2004. 16 p. 